University at Buffalo School of Law

Digital Commons @ University at Buffalo School of Law

$1-1-2008$

\title{
The Legal Profession: From the Revolution to the Civil War
}

Alfred S. Konefsky

University at Buffalo School of Law, konefsky@buffalo.edu

Follow this and additional works at: https://digitalcommons.law.buffalo.edu/book_sections

Part of the Legal History Commons, and the Legal Profession Commons

\section{Recommended Citation}

Alfred S. Konefsky, The Legal Profession: From the Revolution to the Civil War in The Cambridge History of Law in America 68 (Michael Grossberg \& Christopher Tomlins, eds., Cambridge University Press 2008)

This material has been published in The Cambridge History of Law in America edited by Michael Grossberg \& Christopher Tomlins. This version is free to view and download for personal use only. Not for re-distribution, re-sale or use in derivative works. (C) Cambridge University Press 2008.

\section{IN COPYRIGHT}

This Book is brought to you for free and open access by the Faculty Scholarship at Digital Commons @ University at Buffalo School of Law. It has been accepted for inclusion in Contributions to Books by an authorized administrator of Digital Commons @ University at Buffalo School of Law. For more information, please contact lawscholar@buffalo.edu. 


\title{
THE LEGAL PROFESSION: FROM THE REVOLUTION TO THE CIVIL WAR
}

\author{
ALFRED S. KONEFSKY
}

The American legal profession matured and came to prominence during the century prior to the Civil War. The profession had entered the Revolutionary era in a somewhat ambiguous state, enjoying increasing social power and political leadership, but subject to withering criticism and suspicion. Its political influence was clear: twenty-five of the fifty-six signers of the Declaration of Independence were trained in law; so were thirty-one of the fifty-five members of the Constitutional Convention in Philadelphia; so were ten of the First Congress's twenty-five senators and seventeen of its sixty-five representatives. And yet, just three weeks after the signing of the Declaration of Independence, Timothy Dwight - Calvinist, grandson of Jonathan Edwards, soon to be staunch Federalist, tutor at Yale College and, within several decades, its president - delivered a commencement address in New Haven full of foreboding, particularly for those among the graduates who would choose the legal profession. What would await them? Little but " $[t]$ hat meanness, that infernal knavery, which multiplies needless litigations, which retards the operation of justice, which, from court to court, upon the most trifling pretences, postpones trial to glean the last emptyings of a client's pocket, for unjust fees of everlasting attendance, which artfully twists the meaning of law to the side we espouse, which seizes unwarrantable advantages from the prepossessions, ignorance, interests and prejudices of a jury, you will shun rather than death or infamy." Dwight prayed that, notwithstanding, "[y]our reasonings will be ever fair and open; your constructions of law candid, your endeavors to procure equitable decisions unremitted." And he added an historical observation:

The practice of law in this, and the other American States, within the last twenty years has been greatly amended; but those eminent characters to whom we are indebted for this amendment, have met with almost insurmountable obstructions to the generous design. They have been obliged to combat interest and prejudice, powerfully exerted to retard the reformation: especially that immoveable bias, a 
fondness for the customs of our fathers. Much therefore remains to be done, before the system can be completed. ${ }^{\mathrm{I}}$

In one short valedictory diagnosis Dwight captured the essence of the dilemma that would stalk the profession throughout the succeeding century. Was law a public profession or a private profession? Did lawyers owe a special obligation through their learning, education, role, and place in society to the greater good of that society, or was their primary loyalty to their clients (and by extension to themselves)? Could lawyers credibly argue the intermediate position, that by simply representing the private interests of their clients they also best served society?

Dwight's address, first published contemporaneously in pamphlet form, was later reprinted in 1788 in The American Magazine. Alongside Dwight's lofty sentiments there also appeared a far less elevated essay, "The Art of Pushing into Business," satirical advice from an anonymous author, Peter Pickpenny (reportedly a pseudonym for Noah Webster). This essay has been largely ignored. Nevertheless Pickpenny's observations deserve attention, for he too picked up on the old refrain. "Are you destined for the Law?" he wrote. "Collect from Coke, Hale, Blackstone, \&c. a catalogue of hard words, which you may get by heart, and whether you may understand them or not, repeat them on all occasions, and be very profuse to an ignorant client, as he will not be able to detect a misapplication of terms." And again: "As the success (or profit, which is the same thing) of the profession, depends much on a free use of words, and a man's sense is measured by the number of unintelligible terms he employs, never fail to rake together all the synonymous words in the English, French and Latin languages, and arrange them in Indian file, to express the most common idea." And finally: "As to your fees - but no true lawyer needs any advice on this article."

Peter Pickpenny in his own way reinforced Dwight's disquisition on the danger and temptation of the pursuit of purely private gain. Lawyers chased their own private, selfish interest. Contrary to professional lore, they would dupe their own clients while professing to represent them. At the very moment that the Republic was relying on lawyers to reconstitute the form of government, the repository of the ultimate public virtue, their capacity for public virtue was - at least for some - in doubt. Legal ideas were about the nature of the state and the theory of republican civic virtue,

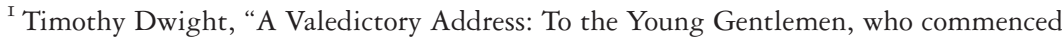
Bachelors of Arts, at Yale College, July 25th, I776," American Magazine (Jan. 1788), 99, IOI.

2 "Peter Pickpenny," "The Art of Pushing into Business, and Making Way in the World," American Magazine (Jan. I788), I03, I03, I05.
} 
but lawyers lived in the marketplace constituted by private interests. That crucial intersection between public and private was where lawyers' roles and reputations would be determined, rising or falling depending on the perception and reality of whether the twain could ever properly meet.

It is tempting to invoke for the legal profession in the century after the Revolution the iconic category (or cliché) of a "formative" or, perhaps, a "transformative" era. But it is not exactly clear that any such label is satisfactory. What we know is that the legal profession evolved in some ways and not in others. The century was clearly of critical importance in the growth of the profession. In 1750 the bar was in many respects an intensely local, perhaps even provincial or parochial profession, more like a guild than anything else. By I 860 it was poised on the verge of exercising truly national political and economic power. During the intervening years, lawyers began to exhibit the classic signs of modern professionalism. They began to cement control over admission to what they defined as their community, through education (knowledge, language, technical complexity) and social standards. They began to regulate their own behavior after admission to practice, to shape the market for their services, and generally to enhance their status in society. Lawyers encountered values, ideas, and self-images embedded in a world of developing and expanding markets, increasingly at a remove from the rhetoric of republican virtue. This new world provided both opportunity and temptation.

Though they never missed a chance to lament their changing world, lawyers displayed a remarkable ability to adapt to opportunity and temptation. Their educational methods slowly altered, the numbers admitted to the profession expanded, the organization of practice gradually shifted, lawyers adapted their practices to legal change, and they occasionally forged that change themselves. The profession helped reshape professional rules of conduct to meet the demand of new marketplaces. Lawyers simultaneously complained about change and embraced it. The public did not really understand what they did, they said, so attacks on their behavior were misplaced. Yet they also tried to convince the public it was wrong, or - subtly changed their conduct to address the criticism. The public's skepticism always haunted the profession, particularly as lawyers began to exercise political power. In a society that moved in theory from trust that elites would exercise their judgment in the best interests of all to suspicion of the legitimacy of elites to retain or exercise power at all, lawyers believed they had no choice but to open up their profession. Still, in a culture outwardly unwilling to tolerate signs of special status, lawyers kept struggling to maintain control of their own professional identity. 


\section{LAW AS A PROFESSION IN THE NEW REPUBLIC}

The legal profession prior to the Revolutionary era is not amenable to easy summary. Across some I 50 years, lawyers in different colonies underwent different experiences at different times. Before I 700, colonies occasionally regulated various aspects of lawyers' lives, from bar admission to fees. The bar's internal gradations and hierarchies in England (between barristers and solicitors) did not entirely survive transplantation in America, where the paucity of lawyers seemed to undermine the necessity of creating ranks. Suspicion of attorneys, often as a carryover from religious life, existed in some places. The Massachusetts Bay Colony's system of courts and judges flourished at times without lawyers at all - no doubt viewed by the Puritan elders (perhaps contrary to their sensibilities) as some evidence of heaven on earth.

By the beginning of the eighteenth century, more lawyers were entering professional life. Lawyers followed markets for their services; they were to be found primarily in seaboard areas where the colonial populations tended to cluster. Accurate figures for the number of lawyers in colonial America have not been compiled, but estimates suggest about a half-dozen in the Pennsylvania colony around 1700 rising to at least seventy-six admitted between 1742 and 1776 ; about thirty to forty in Virginia in I680, many more a hundred years later, and prominent and prosperous as well; about twenty in South Carolina (primarily Charleston) in $176 \mathrm{I}$, thirty-four or so in I $77 \mathrm{I}$, and fifty-eight in I 776 . Figures vary for New York, from about I 75 from $\mathrm{I} 709$ to $\mathrm{I} 776$, to about 400 for the longer period from I 664 to I 788 (about 50 in New York City alone from I695 to I769). In Massachusetts, there were only fifteen trained lawyers in 1740 (one lawyer per slightly over ten thousand people); in 1765 , there were fifty lawyers for a population of about 245,000; in 1775 , a total of seventy-one trained lawyers. With an estimated population of one-and-a-half million people in the British colonies in 1754 , the numbers of lawyers were trifling, if not insignificant.

The social power and influence of colonial lawyers far exceeded their numbers. As the colonial economy expanded, trade increased, and populations grew, the number of lawyers followed suit. Some prospered (though others struggled financially). More important, as the Revolution approached, arguments both for and against independence were forged by lawyers, drawing on their education, training, and experience. Attorneys familiar with arcane land transactions and property rights or routine debt collections came to represent the public face of a political class seeking revolution and independence. Some were cemented to Revolutionary elites through marriage and kinship networks, but other than personal ties and a familiarity with 
political and historical ideas related to law, it is unclear why law practice should have become associated with the Revolution: revolution might just as easily be construed as a threat to law. Aware, perhaps, of the anomaly, lawyers recast the Revolution as a purely political act that changed the form of government, but maintained and institutionalized reverence for law. The outcome was somewhat paradoxical. On one hand, it became accepted in the new United States that the sanctity of law lay at the very core of civic virtue; on the other, that the actual business of representing clients involved in legal disputes was potentially corrupting. In public roles, lawyers might be admired. As attorneys in private practice, they were condemned all too often.

\section{IDEOLOGY AND THE PROFESSION}

In the aftermath of the Revolution the legal profession appeared in disarray. Tory lawyers - by some estimates, 25 percent of all lawyers - fled. The remainder struggled to adapt to a new legal environment, untethered from the English common law and its authority. But the profession's disarray has been exaggerated. Though there is no question that there were Tory defections (particularly in Philadelphia, Boston, and New York), their numbers were rather fewer than reported, particularly in some of the new states. As for the remainder, they quickly burnished their images in the glow of republican ideals while grasping new market opportunities.

\section{Lawyers' Republicanism}

To understand the social function of the nineteenth-century American bar, it is necessary to crack the code of republicanism. Republican ideals focused on the identification and pursuit of a public good or interest that, in theory, was located in a shared belief in civic virtue. Private interest was to be subordinated, and responsibility for administering the public welfare delegated to a natural elite that would place the commonwealth's interest above all else. Republican governors would derive their authority from general recognition of their character, merit, and demonstrated ability, not from their inherited role or hierarchical position in society.

The republican ideal presented both opportunity and challenge for the legal profession. The American version of revolution was primarily driven by ideas. One might consider lawyers an unlikely repository of revolutionary fervor, but patriot practitioners certainly had preached ideas - notably separation from the crown - and were responsible, therefore, for developing a replacement. The public good was thus deposited substantially into the hands of lawyers; their responsibility was to frame forms of government 
that would guarantee the civic virtue on which the future of the Republic depended.

For lawyers turned politicians/statesmen, the keys were twofold, constitutions and the common law, both envisaged as foundations for institutions that would restrain or limit the power of the state and ensure liberty. Rules were the purview of lawyers. Pay attention to the carefully crafted and drafted rules distilled from the voices of experience drawn from the ages. You will get social order and control, and avoid the threat of licentious freedom. Or so the lawyers believed.

But the lawyers were reluctant to leave anything to chance. Here opportunity met its challenge. The lawyers who drafted the Republic's constitution were afraid that the document itself, placing sovereignty in the people and deriving its authority from the consent of the governed, might in fact be more democratic than republican. Lacking faith in the capacity of the people to abide by the limits of the Constitution and behave within its restraints, the founders hence sought to create additional means to mediate between the Constitution and its core values and popular rule; to protect the people from their own excesses. Fifty years after the Revolution, lawyers were still delivering anxious jeremiads that reflected on their fears for the republican legacy with which they had been entrusted. In I 827 , Lemuel Shaw, then practicing law in Boston a few years before being appointed Chief Justice of the Massachusetts Supreme Judicial Court, enjoined his colleagues of the Suffolk County bar to "[guard] with equal vigilance against the violence and encroachments of a wild and licentious democracy, by a well balanced constitution." Well balanced meant "a constitution as at once restrains the violent and irregular action of mere popular will, and calls to the aid, and secures in the service of government, the enlightened wisdom, the pure morals, the cultivated reason, and matured experience of its ablest and best members" - people like themselves. ${ }^{3}$ It was not enough to write the documents and then get out of the way. Lawyers should be the checks and balances too.

The danger was that the public would accuse lawyers of being undemocratic for intervening in the political process, for trusting neither the constitutional institutions they had created nor the citizens they had placed in positions of responsibility to undertake their own wise self-government. Ironically, however, the public documents of revolution were rule-bound. Lawyers were positioned to interpret and apply them in two distinct capacities, first as participants in the public process of creating rules of selfgovernment (laws), and second as interpreters and practitioners of law - as

\footnotetext{
${ }^{3}$ Lemuel Shaw, An Address Delivered before the Suffolk Bar, May I827, extracted in American Jurist and Law Magazine 7 (1832), 56, 61-62.
} 
providers, that is, of services to fellow citizens who were, in their own interests, navigating the system the lawyers had themselves developed.

Here we meet the second hallmark of the post-Revolutionary profession: its new, enhanced role in the process of dispute resolution. As the meaning of republican virtue changed and became increasingly contested, what emerged was a new kind of constitutional faith that interests and factions would ultimately balance each other out and that no one interest would ultimately dominate the polity. Given that a lawyer's job was to represent interests, the new republicanism dovetailed neatly with a professional norm that insisted on pursuing the best interests of clients in an adversarial environment. If the Constitution and the common law created a framework within which private interest had to be recognized, who better than lawyers to mediate between these interests by getting everyone to play by the rules, by laws, and by procedures so that social order and not chaos would ensue? The problem, of course, was that lawyers could be accused of fomenting private disputes for their own personal gain and of tearing at the fiber of society, rather than preserving it. The lawyers' response was that they were only representing the interests that the country's constitutions recognized and that they would be shirking their republican responsibilities if they did not participate in the system of resolving disputes that helped preserve the rule of law. There was public virtue in representing the interests of others.

But lawyers still wanted to be the "best men," the dedicated, dispassionate elite that would guide the Republic. Lawyers by training and education, familiar with classical antiquity and its lessons, would form a learned profession, a natural calling, that would replace the ministry as society's preferred leaders. Particularly well situated by preparation to participate in a government of laws, attorneys could as a profession shepherd post-Revolutionary America through daily life, or through the most trying times, just as they had through the Revolution itself.

To accomplish all these tasks, lawyers had to maintain some control over who was admitted to the practice of law. From an early date they emphasized moral character as a determining factor in bar admission almost as much as acquired knowledge. Lawyers acted as gatekeepers to the profession: only those judged safe in the wake of the Revolution were deemed worthy of admission and its consequent public and social responsibilities. A halfcentury after the Revolution, Tocqueville captured part of this idea when he referred to lawyers as an "American aristocracy." Tocqueville's observation had many meanings, but as part of his characterization of this aristocracy he noted "[t]hat the lawyers, as a body, form the most powerful, if not the only, counterpoise to the democratic element." 4 Elites, independent and

\footnotetext{
4 I Alexis DeTocqueville, Democracy in America (Phillips Bradley ed., I945), 278.
} 
not dependent members of society, could be trusted to identify the true public interest in a society reduced to competing, potentially ungovernable, and exuberant private interests. Or at least, so the rhetoric of the bar proclaimed. The risk was that elites could be corrupted by their own private interests (always just around the corner in a market society) or that the bar could be viewed through its admission control mechanisms as a monopoly restricting opportunity or, in a related sense, could be accused of a lack of commitment to democracy and, even worse, of resisting change or the will of the people by asserting a preference for order. Republicanism, then, appeared to grant post-Revolutionary lawyers three major vocational opportunities - mediating between government and the sovereignty of the people by fostering the public good, providing the services of dispute resolution in a society of competing interests, and maintaining a disinterested bar trained to exercise enlightened leadership. All, however, would turn out to be unresolvable tensions in the life of the bar between the Revolution and the Civil War. The difficulties they posed were played out over and over again - in legal education; in bar admission, composition, and structure; in the organization of practice; in law reform; in ethics; and elsewhere. The bar never could quite escape the ambiguity of its role in American society.

\section{Anti-Lawyer Critiques in the Republic: Defining the Public Good and the Nature of Community Under Law}

Not everyone thought American lawyers were living up to the republican creed. There has long been an anti-lawyer tradition in America, although it is not exactly clear whether the Revolution exacerbated or eased it. But some post-Revolutionary critics, for political and other reasons, clearly believed that lawyers were far from paragons of civic virtue, and their attacks tried systematically to stymie the attempts of attorneys to align themselves with the constituent elements of republicanism. There was a certain irony to this criticism, for it showed that lawyers' dual capacities rendered them vulnerable as well as powerful. Through their active participation in the founding of the nation, lawyers had worked hard to institutionalize the insights of republican theory as well as to situate themselves as public representatives of it. As private lawyers, however, they could be found wanting in a wide variety of interrelated ways that served to undermine their carefully constructed public role.

First, there was the perpetual, vexing problem of the complexity of law. Law in a republic ought to be accessible to all, not the special province of experts. The more technical and complex the law - with only lawyers qualified to administer, superintend, or interpret it - the more costly and the less accessible it became. The call came to simplify the words and cut 
the costs. One radical program, suggested in Massachusetts by Benjamin Austin in I 786 (and republished in I 8 I9), was simply to abolish the "order" of lawyers altogether. Similarly, the citizens of Braintree asked for laws that would "crush or at least put a proper check or restraint on that order of Gentlemen denominated Lawyers" whose conduct "appears to us to tend rather to the destruction than the preservation of this Commonwealth." 5

If the state found it impractical to control lawyers, then perhaps communities could reduce reliance on the artifice of law as practiced by lawyers. Lawyers' "science," some critics charged, cut law off from its natural roots in justice. In the immediate post-Revolutionary generation, they proposed ways of restoring the quasi-utopian, pristine quality of law. Massachusetts, Pennsylvania, and Maryland all considered legislative proposals to embrace arbitration procedures that would wrest control of the administration of justice from lawyers and simplify the legal process. Arbitration was also occasionally linked to court reform. As one Maryland observer noted, "The great mass of the people have found business to proceed much faster by mixing a little common sense with legal knowledge... I know many private gentlemen, who possess more accurate legal erudition than the majority of attorneys, although, perhaps, not so well acquainted with trick and finesse."

Second, as practicing attorneys, lawyers appeared merely self-interested, rather than interested in the public good. As the citizens of Braintree hinted, self-interest threatened the fabric of the community by pitting citizens against each other. At the very least, lawyers exacerbated conflicts by representing opposed parties. Worse, as Jesse Higgins observed in I 805 in Sampson Against the Philistines, lawyers might actually foment conflict for their own purposes, rather than prevent or resolve disputes. In I 830, in Vice Unmasked, P. W. Grayson stated the problem concisely: "Gain I assert is their animating principle, as it is, in truth, more or less of all men.... A tremulous anxiety for the means of daily subsistence, precludes all leisure to contemplate the loveliness of justice, and properly to understand her principles." $R$ Rather than belonging to a learned profession or a higher calling, Grayson suggested, lawyers were now embedded like everyone else in the marketplace. Self interest in an increasingly atomized society was the norm, and lawyers were no exception; in fact they seemed particularly susceptible to falling victim to corruption and luxury.

Third was the problem of independence in a republic that rejected forms of dependence and subordination. Lawyers were in an ambiguous position

\footnotetext{
${ }_{6}^{5}$ Petition of the Braintree Town Meeting, Sept., I 786.

${ }^{6}$ Baltimore American, Nov. 29, I 805 (italics in original).

${ }^{7}$ P. W. Grayson, "Vice Unmasked, An Essay: Being A Consideration of the Influence of Law upon the Moral Essence of Man, with other reflections" (New York, I830).
} 
or, perhaps, a double bind. On the one hand, lawyers represented others, clients, so the claim could be made that they were dependent on others for their business or that they were not independent producers, free of others, and self-sustaining. On the other hand, one of the aspects of republican lawyering could be construed as reserving to the attorney the right to make independent moral judgments about the virtue of the claims of clients on whom he depended for a livelihood. Would clients tolerate the substitution of the will of their attorney for their own will when clients thought that they were purchasing expertise and knowledge in the marketplace? Was the independence so prized by republican theorists fated to be eternally compromised by the social function of lawyering? And what about the perceptions of clients? In a society that valued independence, would clients resent being in the thrall of their lawyer, who possessed a grip on language and technicality? In a society that talked openly about the promise of equality, clients might chafe if they were placed under the protection of another person, dependent on his expertise.

It was equality, finally, that caused lawyers their most pressing ideological problem. Republicanism required selfless, educated, virtuous elites to lead and govern. Lawyers thought they were well suited to the task. They had forged connections or networks with other elites through marriage or kinship and also through business and economic transactions, which nevertheless contributed to the image of attorneys as dependent. Moreover, obsessive and risky land speculation led some lawyers into financial distress. Yet in a society that also valued the equality, individuality, and independence of its citizens, pretensions to leadership suggested pretensions to aristocracy and hierarchy. Lawyers had not been elected in their professional lives, though the charge was that they acted as if they were. (In Jacksonian America, this insight helped fuel the move to elect judges.) In their public lives they did often serve in elected political office, shaping public policy in part through their legal insights, not associating overwhelmingly with one political party or ideology.

Inevitably the bar's claims to elite status became caught up in the maelstrom of Jacksonian democracy. In I 832, Frederick Robinson jeered at lawyers' pretensions: "And although you have left no means unattempted to give you the appearance of Officers, you are still nothing more than followers of a trade or calling like other men, to get a living, and your trade like other employments, ought to be left open to competition." 8 Though his words were anti-monopolistic in tone, with implications for the educational

\footnotetext{
${ }^{8}$ Frederick Robinson, "Letter to the Hon. Rufus Choate Containing a Brief Exposure of Law Craft, and Some of the Encroachments of the Bar Upon the Rights and Liberties of the People" (I832).
} 
and admissions process, the heart of the matter was equality of opportunity. Should the profession be less of a closed fraternity with the de facto right to exclude entry, particularly if the bar was associated with economic power? The common law was not supposed to be mysterious, but available to all. The Constitution was supposed to apply to all. So the legal profession should be open to all - though whether increasing the number of lawyers was a good idea or a bad idea seemed not to concern Jacksonian theorists, any more than the question whether simplifying the law through codification would cause lawyers to behave any differently once they were trained in the mysteries of the craft.

Though criticism of lawyers was widespread, it was not crippling. In some places, indeed, it seemed rather muted. Lawyers did not appear to be viewed as a particularly potent or threatening social or political force in Southern society. Their reputation, perhaps more myth than reality, placed them in a rather more genteel classification: well educated, well read, tied more closely to the planter elites and their culture, more interspersed in society, and often practicing law only when it suited them. Prosperous Southern lawyers often invested in land, plantations, and slaves, seamlessly blending with their culture rather than standing apart from it. Perhaps there was a lesson in their experience for other lawyers. Their major moral challenge was their involvement in a slave society, but most seemed to concern themselves simply with administering the system internally, coping with its contradictions and inconsistencies, rather than spending much time, at least at first, defending the system from external ideological attacks. They just acted like lawyers.

So both lawyers embracing republicanism and republican critics of lawyers helped shape the contested images that would follow the profession in various forms and elaborations throughout the century. Was it declining or was it rising? Was it a learned profession or a business? Was it selfless or self-interested? Was it public spirited or private oriented? Was it political or apolitical? Was it independent or dependent?

\section{THE EDUCATION OF LAWYERS: THE SEARCH FOR LAW AS A SCIENCE IN A REPUBLIC}

\section{Apprenticeship}

For most of the eighteenth and nineteenth centuries, the overwhelming majority of American lawyers were trained by other lawyers through what was known as the apprenticeship method, a method apparently conceived of as if its purpose was to train fledgling artisans in the mysteries of a craft or guild. Special knowledge and expertise were to be imparted by those solely 
in control of that knowledge to those wishing to enter a "profession" that was responsible for defining itself. Admission to the educational process was tantamount to admission to the profession, because the standards for bar admission were primarily established by the bar with occasional supervision by the courts. Those standards tended to prescribe a period of time "reading law" in an attorney's office, followed by only the most rudimentary examination by a judge. Whether one obtained a solid legal education was mostly fortuitous. There was not much method to the process, scientific or otherwise.

By necessity, therefore, almost all legal education was local. Potential students - often by dint of personal association or friendship, community, and family - enlisted in the offices of attorneys in their towns or metropoli$\tan$ areas and agreed to pay a tuition of $\$ 100$ or $\$ 200$ (waived on occasion) to receive an "education." Though the education was decentralized, it was remarkably uniform. From the late eighteenth through the first quarter of the nineteenth century, law students began by reading primarily what their mentors had read before them. The process often started by reading general historical and jurisprudential works focusing on the feudal origins of law, or the law of nations or natural law. From the general, the educational program moved to the particular. The great advance in legal education at this time was provided by Blackstone's Commentaries, absorbed by generations of grateful law students. Arranged by systematic legal categories, the Commentaries provided complex yet concise insights and an overview into foundational legal principles. Blackstone also took the pressure off lawyers actually to teach, allowing them to carry on business (also using the cheap labor supplied by students), which the students might also observe.

After reading, students were expected to organize their own knowledge. They did this by compiling their own commonplace books, which distilled their readings into accessible outlines. Whether learning lessons from Blackstone (or St. George Tucker's later American version of Blackstone, or Kent's own Commentaries) or copying the writs, declarations, or answers of the attorneys in whose offices they read, the students, often unsupervised, in theory assiduously mastered the accrued lessons of the past filtered through the remarkably similar experiences of their teachers in the present. As a result, a certain regard for tradition, continuity, and timelessness was transmitted. Over time, the educational process was enhanced as judicial decisions became more available through case reports and legal treatises on more specialized subjects were published. Even then, a student's exposure to these materials was often at the mercy of the library of the law-office attorney.

A legal education could be haphazard, and as many students complained, it was almost always drudgery. At the dedication of the Dane Law School 
(Harvard) in I 832, Josiah Quincy described the current form of legal education in need of reform. "What copying of contracts! What filling of writs! What preparing of pleas! How could the mind concentrate on principles." Books, said Quincy, "were recommended as they were asked for, without any inquiry concerning the knowledge attained from the books previously recommended and read. Regular instruction there was none; examination as to progress in acquaintance with the law - none; occasional lectures - none; oversight as to general attention and conduct - none. The student was left to find his way by the light of his own mind." The result was boredom, inattention, ignorance. "How could the great principles of the law ... be made to take an early root . . by reading necessarily desultory ... and mental exercises ... conducted, without excitement and without encouragement, with just so much vagrant attention as a young man could persuade himself to give...." 9

Reading law, therefore, was thought of as a practical education, technical learning by osmosis, but an education where acquiring the principles of the mysterious science was left to chance. There was much unhappiness with the methodology, but precious little change or thought about change. A prospective student understood that the critical step in the process was finding an office in which to read because, by rule or custom in most places, after three years or so of tedious endurance, bar admission would result. The bar decided who was worthy enough to enter the profession. The members of the bar were primarily a homogeneous group, and they generally rewarded those who were striving and seeking opportunity. To read law, one did not have to come from a wealthy family (merchants or planters), and though wealth helped a young man get accepted into a law office and pay his tuition, plenty of farmers' or ministers' sons found their way there. Also, having some form of undergraduate college education clearly helped - indeed, over time in some jurisdictions, the bar rules would require some formal education. But the search for organizing principles and alternative methods was only beginning.

\section{University Law Professors}

University law lectureships and professorships never really flourished in immediate post-Revolutionary America. Seeking to emulate Blackstone's success as Vinerian Professor of Law at Oxford, a small number of universities created professorships or chairs. The experiment began, thanks to Thomas Jefferson, with George Wythe's 1779 appointment at William and

\footnotetext{
${ }^{9}$ Josiah Quincy, "An Address Delivered at the Dedication of the Dane Law School in Harvard University, October 23, I 832."
} 
Mary as professor of "Law and Police." (Wythe would be followed in the position by St. George Tucker.) Wythe's professorship, mostly because of his gifts and intellect, was to be the most successful of these attempts at legal education, but other examples abound in the I790s - from the important law lectures of James Wilson at the University of Pennsylvania and James Kent at Columbia (though after the initial ceremonial lectures, interest and students seemed to wane), to David Hoffman's ambitious undertaking at the University of Maryland in I8I4. Along the way Harvard, Virginia, and Yale began offering undergraduate law courses that over time evolved into university law schools.

In addition to signifying discontent with the apprenticeship custom, all these fledgling programs had one purpose in common. The lectureships stemmed from a conviction that law was to be a learned profession and that law, if not yet a science, was certainly one of the liberal arts essential to teaching and learning about the nature, place, and role of civic virtue in a newly minted republican society. If this society was to be self-governing, it needed to educate an elite that would understand the lessons of the past and devise institutions, legal or otherwise, to prevent the mistakes of the past from recurring. So, although there was some discussion of practical legal detail, the emphasis was on organizing knowledge about the law to establish an impact on the shape of society. Society would not be safe without republican lawyers.

\section{Proprietary Law Schools}

Proprietary law schools arose in the United States to fill a perceived vacuum. No one was teaching principles, and the grasp of the practical was assumed to flow seamlessly from observation and repetition. Lawyers also for the most part could superintend only a handful of students, and if no lawyer was available, a prospective student might have to travel or be inconvenienced. Monopolizing students might be frowned on, and so in some senses, it might be more efficient to form a school to attract a variety of students from a variety of places, particularly if the school could guarantee that they would be getting plenty of attention, organization, and books they might not find elsewhere.

Such was Tapping Reeve's insight and gamble when he founded the Litchfield Law School in a little corner of Connecticut in 1784. Reeve, eventually in partnership with James Gould, and finally Gould by himself, trained about one thousand lawyers (many of whom served in important positions in politics and law) before their doors closed in $\mathrm{I} 833$, perhaps as a result of the competition emerging from university law schools, particularly Harvard. 
Reeve and Gould offered rigor, supervision, and lectures. Over the course of fourteen months, students heard ninety-minute daily lectures organized around legal principles (not just the mindless rote of rules), recorded their lessons in notebooks, took weekly tests, and participated in forensic exercises. The measure of Litchfield's success is that though students were drawn primarily from the New England and mid-Atlantic states, the school's reputation was such that despite its relative isolation and Federalist proclivities about 30 percent of its enrollees were from the South, including John C. Calhoun.

Litchfield's reputation inspired other attempts by lawyers and judges to earn a living teaching law or to supplement their income by aggregating student apprentices. None of these efforts achieved the same level of broad acceptance and intellectual impact as Litchfield. But they appeared and then disappeared with various degrees of seriousness in localities in Virginia, North Carolina, New York, Massachusetts, and elsewhere. Their lack of infrastructure and financing, coupled with the slow reexamination of the ideas justifying the forms of legal education, eventually led some to believe that the place for the education of lawyers belonged in a university that could justify professional, as well as undergraduate, training.

\section{University Law Schools}

Joseph Story had such a vision. In I 829, beginning with the remnants of the endowed law professorship established at Harvard College more than a decade earlier, Story sought to transform the nature of legal education. A simple law professorship would no longer do; Litchfield showed that. Apprenticeship left too much to the risks of mentor inertia and student indifference. What was needed was systematic endeavor demonstrating that law was a science and belonged in a university. The question was, what kind of science. Story preferred to see law as a set of ideals, stressing universal principles of natural justice, spanning the ages and ever appropriate. Law was a moral science designed to guide human behavior. It was important, he thought, in a republic to develop a cadre of specially trained guardians, "public sentinel[s]," Io to protect, as Lemuel Shaw had put it, against the excesses of democracy. Ever mindful of the spread of Jacksonian democracy, Story wanted to guarantee that lawyers would retain strong moral character. If lawyers could not control admission to the profession, they could at least control the content of a lawyer's education. Republican virtue must be perpetuated, sound principles enunciated clearly, governing standards declared. Training lawyers also meant sending them out into the world.

${ }^{\text {Io }}$ Joseph Story, "Discourse Pronounced Upon the Inauguration of the Author as Dane Professor of Law in Harvard University (Aug. 25, I 829)." 
Timothy Walker, who founded the Cincinnati Law School in I835 in the image of Story and Harvard, was one. If they came to Harvard to learn, Story wanted them to populate the nation as missionaries.

Story's reach was national. Systemization of thought for him meant forming and shaping the general legal categories with which to organize a legal literature designed to tell lawyers how to believe or act. Story contributed greatly to his cause by writing innumerable legal treatises, ranging from Commentaries on the Constitution to various technical legal subjects. For Story, theory was practical. The success of Harvard Law School rose during Story's tenure and began a generation of decline on his death in I 845 .

Not all who sought refuge in a university legal education shared Story's vision. Different ideas about the nature of legal education and legal science flowed from the rationality preached by the philosophers of the Scottish Enlightenment. Tied to what became known as Protestant Baconianism, which was rooted in natural theology and eventually the natural sciences, the recommended method was one of taxonomical classification that organized knowledge and the acquisition of knowledge from the bottom up around readily recognizable first principles, instead of from the top down, as Story advocated. The Baconian system of legal thought - espoused by lawyers and law professors like David Hoffman, David Dudley Field, George Sharswood, and, most ominously for Story, his colleague at Harvard, Simon Greenleaf was supposed to be verifiable and vaguely empirical. This method, because it was more scientific, arguably had the virtue of being able to adapt better to social change. Story did not much like change, particularly political change. The loosely knit Protestant Baconians wanted to adapt law to American experiences (an idea that Story in theory was not opposed to) and to release it from its perceived dependence on pre-Revolutionary British common law. Law needed to be explained as a science, not simply as a faith. Seeking to train lawyers based on these principles, the Baconians saw lawyers more as specialists or experts, technocrats providing a service in the marketplace, though they retained concerns about the moral responsibility of lawyers. Story apparently was afraid that unless his method was used, the republic, founded under the stewardship of lawyers, would fade away, and that lawyers would no longer be part of a learned profession and noble calling. And indeed, the face of the profession was gradually changing, just as Story feared.

\section{THE GROWTH OF THE PROFESSION}

Over the course of the nineteenth century, lawyers, in conjunction with courts, gradually lost whatever control they had over admission standards and practices. In 1800 , fourteen of the nineteen states had requirements of between four to seven years of bar preparation. By i 840 , only eleven of the 
thirty states insisted on prescribed periods of study. In jurisdictions like Massachusetts and New York, before the liberalization of rules governing admission, it might take a prospective lawyer up to a decade (including a fixed period of college education) to qualify for admission. By mid-century that had changed drastically. Good moral character with a shortened period of study or an examination became the standard in Massachusetts in 1836 . New Hampshire in I842 and Maine in I843 required only evidence of good moral character, without any prescribed period of study. By I860, just nine of the thirty-nine states insisted on any period of study. University legal education, which promised to help filter entry to the profession, was still slow to gather momentum, with about fifteen university law schools operating in I850. These changes fed concerns about the composition of the bar that reignited disputes within the profession and the public over the proper place of lawyers in American society.

The bar was forced to open up under pressure from forces loosely associated with Jacksonian democracy that produced leveling arguments coupling equality of opportunity with suspicions about elites. The relaxation of admission requirements has often been bemoaned in the literature of the profession as a period of great decline. But it is difficult to determine the baseline against which to measure the fall from grace, or to assess precisely how many lawyers were entering practice, or who they were. The traditional view was that the bar was a meritocracy (thereby ensuring its status as an honestly earned craft or guild or elite). In I 84 I, St. George Tucker observed that "the profession of the law is the most successful path, not only to affluence and comfort, but to all the distinguished and elevated stations in a free government." I I On the other hand, lawyers from John Adams onward had expressed concerns that increasing numbers of lawyers meant more unscrupulous, untrained pettifoggers clogging the courts, stealing clients, and leading the public to believe all attorneys were mendacious predators; and that, even worse, the practice of law had become a mere business.

There are very few reliable statistics on the number of lawyers in the United States between 1790 and I 850 ; most of the evidence is fragmentary, scattered, and anecdotal. Before 1850 , there are limited data on the number of lawyers in some locations at some specific times. The federal Census of I 850, however, broke down occupations by location or state. It recorded just under 24,000 lawyers nationwide, almost half of them in only five states: Massachusetts, New York (with nearly i 8 percent of the total alone), Ohio, Pennsylvania, and Virginia. And not surprisingly, by mid-century more lawyers were pushing west into Indiana, Illinois, and Wisconsin.

${ }^{\text {I I }}$ [Henry St. George Tucker], Introductory Lecture Delivered by the Professor of Law in the University of Virginia... 8 (I84I). 
As to the number of lawyers as a proportion of the general population, "[b]etween I 850 and I 870 , the ratio was fairly steady: I.03 lawyers to every I,, 00 population at the beginning and I.07 at the end." ${ }^{2}$ If one compares this data with numbers on the eve of the Revolution, it is clear that by I 850 many more men were entering the legal profession, and the relative number of lawyers in proportion to the general population had increased significantly. Indeed, lawyers in some places complained that the profession had become overcrowded and was degenerating into a mere business, while anti-lawyer critiques decried the "swarms" of lawyers. But in places like New York, the increased number of lawyers might have been a consequence of the accelerating pace of market expansion and trade, as well as the growing complexity of legal practice. And in any event, the impact of lawyers on public policy and political activity may have been disproportionate to their absolute or relative numbers. So, was the ubiquitous lament about the overcrowding and decline of the legal profession in part a complaint about who the new lawyers were?

Only a few brief demographic snapshots analyze data about lawyers' social class and status over the nineteenth century. The two most extensive studies are of Massachusetts and Philadelphia. For Massachusetts, Gerald Gawalt found that, of 2,6 8 trained lawyers practicing in Massachusetts and Maine between 1760 and I840, 7 I percent held college degrees. Admittedly, Massachusetts was hardly the frontier, but in a period when a college education was the exception and not the rule, this data seem scant evidence of the decline of the profession, at least in that state. Gawalt also found that over time most college-educated lawyers in Massachusetts and Maine came from professional families and often were the sons of judges and lawyers. It seems fairly clear that, at least for this period, Massachusetts lawyers retained the gloss of an educated elite, not necessarily upper class, but solidly grounded in the community. A narrower sample of lower federal court judges from I 829 to I86I also indicates the judges were generally from the educated middle class. Western or frontier lawyers, drawn from a different cohort, seem to have been from more humble origins.

In Philadelphia, the story was a little different. From i 800 to I 805 , 68 percent of Philadelphia lawyers were college graduates, and 72 percent came from elite families. By I860, the number of college graduates in the profession had fallen to 48 percent. The pool of prospective lawyers, meanwhile, had expanded. Upper-class representation declined from 72 percent to 44 percent. Where middle-class families were only i 6 percent of the

\footnotetext{
${ }^{12}$ Terence C. Halliday, "Six Score Years and Ten: Demographic Transitions in the American Legal Profession, I850-I960," Law E Society Review 20 (1986), 53, 57. Incidentally, the ratio "rose steeply to I.5 in I900, but then contracted to I.I6 in I920." Id.
} 
sample in I800-1805, now they were nearly half. Twenty-seven percent came from the artisanal and lower middle class. The lower-class group remained steady over time at $\mathrm{I} 2$ percent.

The appearance of a more heterogeneous profession where once there had been a more homogeneous legal community might explain some of the bar's rhetorical crankiness or anxiety about its status. However, agitation about lost status and lost community did not necessarily translate into reduced authority. The middle class was not preaching revolution, just access. This also meant that, as more individuals were engaged in an expanding economy, new markets for legal services would be created. One of the paths to enhanced market participation was to represent those touched by the same invisible hand. Most young lawyers sought entry to the profession to build their own lives, not threaten others.

In any case, there were clear limits to the bar's diversity. At this time, for obvious reasons, the profession remained overwhelmingly white, and male and Protestant. A handful of African Americans became lawyers before the Civil War. Only about six were admitted, beginning with Macon Bolling Allen in Maine in I 844. Allen left Maine within a year, apparently clientless, and was admitted to the bar in Massachusetts in I 845. Robert Morris, Sr., followed suit in Massachusetts in I847, where he established a thriving practice, best remembered for his failed quest to desegregate the Boston public schools in 1848-1849 in Roberts v. City of Boston.

Women fared worse. There is some evidence that women on rare occasions appeared in court on their own or others' behalf, but no women were admitted to the practice of law before the Civil War. Belle Mansfield was admitted to practice in Iowa in I 869, and shortly thereafter, Myra Bradwell, fresh from having founded the Chicago Legal News, passed her bar exam, only to be denied admission, thereby starting the path to the constitutional decision barring her entry to the profession. At this stage, the weight of gender stereotypes was apparently too much to overcome.

By I 860, the bar was growing, with only a few cracks in its facade of social class. It was now a symbol of aspiration, and if indeed it was a higher calling, why would the bar complain about all those aspiring to enter? Anxious about losing status and professional control, the bar continued to fret. For all its concerns its hegemony over law never really seem threatened. However, immigrants, non-Protestants, racial minorities, women, and poorly educated supplicants were looming just over the horizon.

\section{THE ORGANIZATION OF PRACTICE}

Wherever a lawyer during this period might have been located - New England, Mid-Atlantic, Midwest, South, West, or the so-called frontier, Southwest, or eventually the Far West, urban or rural - the chances were 
overwhelming that he was a solo practitioner. And it was just as likely that he was a generalist, prepared to take any business that walked in the door. "In this country," one lawyer commented in I8I9, "there is little or no division of labour in the profession. All are attornies, conveyancers, proctors, barristers and counselers.... It is this habit of practical labour, this general knowledge of business, which connects the professional man in this country with all classes of the community, and gives him an influence, which pervades all." ${ }^{3} 3$ The realities of practice thus also determined the place of lawyers in American society.

A lawyer had to have some facility in pleading and litigation (though just exactly how much litigation actually went to trial is unclear), and the dimensions of a lawyer's expertise might be tested by where he practiced. For example, if a lawyer practiced on the frontier or the old Northwest, or parts of the South, or interior New England from 1790 to about I820, unless he was anchored in a small metropolitan area, he probably rode circuit; that is, took his business on the road following the terms of the courts as they circulated throughout the jurisdiction. Thus, the typical lawyer faced a number of challenges. First, he probably did not know most of his clients until he met them. Second, he had to be a quick study, or at least capable of reducing the great mass of business into a routine processing mode (often just filing actions to preserve claims, particularly debt collections, or appearing to defend them). Third, he had to be nimble on his feet. He had to go to trial with little or no preparation, so some forensic ability might help, including an aptitude for shaping or developing a narrative - telling a good story. Rhetoric might or might not get in the way, although there is some evidence that the trial calendar was treated in some locations (rural as well as urban) as local theater or entertainment. Fourth, a lawyer's reputation was treated as a kind of roving commission: the success of his business depended on his perceived performance. Last, he had to be willing to travel with and develop a tolerance for a group of fellow lawyers and judges. In the absence of bar associations in most places, lawyers boarded and bonded with one another in all kinds of settings. There is a fair amount of bar and other literature heralding the brotherhood of lawyers - looking out for each other's business, for example. There are also accounts of boisterous and occasional violent confrontations between lawyers in the South and West, which sometimes are cited as evidence of their community.

As courts became more centralized, one shift in the method of practice over the century was the reduction of circuit riding, sometimes over the complaints of those who found it difficult geographically to gain access to courts. Though transportation networks were expanding, judges and

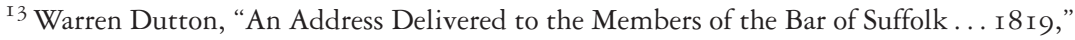
6-7.
} 
lawyers tended to withdraw from traveling, or at least circuit riding was no longer a central identifying feature for some of the bar. Over time in some places in Tennessee, Ohio, and Michigan, lawyers went to clients or physically searched for clients less often; rather the clients came to the lawyers. The market for services had changed.

Attorneys had another reason for choosing solo practice: there was not enough business to support more extensive office practices. Most lawyers made a decent enough living. Some struggled. A few became very rich. By I 830 Lemuel Shaw was earning between $\$ 15,000$ and $\$ 20,000$ annually, a great deal of money in those days. Alexander Hamilton, Daniel Webster, and others also made large sums of money. In New York and in some of the eastern seaboard cities from North to South, lawyers in practices tied to economic expansion and organization prospered by investing or by serving as corporate officers, bank directors, or trustees. Nonetheless, in I 856 John Livingston reported in his national survey of the bar that a lawyer's income averaged about \$I,500 per year, less than most appellate judges' salaries at the time.

This general "sufficiency" does not mean the bar was not stratified. It was, not formally as in England, but by income. Age was one factor. In some places attorneys when first admitted were limited to practice only in lower courts for a probationary period. Young lawyers tended to move west to seek opportunity and avoid competition. The income hierarchy was differentiated further over time in some locales, like cities, based on what courts a lawyer practiced in - courts of criminal jurisdiction, for instance, as opposed to appellate practice. The primary marker of stratification, however, was the lawyer's clients. For a profession that valued its independence, it was remarkable to see a de facto classification of lawyers emerge based on whom they represented.

Closely examined, a simple debt transaction reveals the initial layers of the profession. On one side would stand the debtor, typically starved for cash. His lawyer would spend his time ascertaining the circumstances of the transaction, gathering the documents (probably limited and primitive), responding to pleadings (usually mechanical and rote), but often seeking to postpone the payment or judgment for as long as possible so his vulnerable client could remain afloat. The lawyer had few economic resources or legal strategies available, and he often negotiated or corresponded with the creditor's attorney from a position of weakness. His fee was likely to be small and difficult to collect. He scrambled for business and was fortunate if he could bargain with his opponents to renegotiate the terms of the transaction or arrange a settlement.

The creditor's lawyer, by contrast, operated in a much more stable environment. Legally protected in most circumstances, the creditor asserted his 
rights in the transaction from a position of strength. His lawyer behaved accordingly. He also evaluated the factual setting, counseled his client, negotiated on his behalf, and prepared the pleadings. But the underlying economic circumstances of the creditor were likely, though not always, to be better than the debtor's. Securing a debt for a relatively wealthy client was very different from scrambling to avoid paying a debt for a client with more limited resources. The creditor's lawyer, further, might have been specifically retained with fees to pursue the debt - mercantile firms or banks paid handsomely for lawyers' services, particularly in urban settings, and particularly as, over time, the transactions both in the original counseling and drafting phases became more complex and sophisticated. Thus, although lawyers might share a professional identity of sorts, on any given day, they might be doing very different things with very different consequences growing out of the same subject matter. The different forms of legal practice became segmented over time through repetition. They also became stratified as what the lawyer did increasingly reflected the wealth of the clients he represented.

Over the course of the century, the wealth of the client was more likely to be corporate, not individual. Here lay major engines of stratification - retention and repetition. An individual landowner might need an attorney occasionally for buying and selling land or arranging leases or easements. But what if a newly chartered railroad sought to take or cross his land? Suddenly the quiet enjoyment of his property became a major problem. Meanwhile his attorney - attuned to bread-and-butter miscellaneous disputes or minor property matters - might find himself confronting a new phenomenon, the retained railroad lawyer, professionally sophisticated and with substantial client resources at his disposal. The railroad attorney might have helped draft the legislative charter creating the enterprise (and lobbied for it politically with fellow lawyers), arranged and secured financing for the project (and drafted those documents as well), fended off the competing claims of other competitive roads or corporations (with their own retained attorneys), overseen the eminent domain or taking proceedings before nascent administrative bodies or the courts, negotiated complex deals, and generally dealt with a host of railroad-related matters. Hired railroad attorneys were very polished repeat players in the expansion of economic development projects. Landowners and their generalist lawyers were not. The enterprise or corporate lawyers tended to separate themselves from other strata of the profession through their specialization and economic success and, therefore, exercised more social and political power.

The emergence of a segmented and stratified profession was reinforced by social kinship and family networks. Bar elites cemented their social and political status and power by alliances with entrepreneurs: lawyers' families 
were often connected by marriage to fledgling industrial capitalists in New England, or to the owners of large manorial land holdings or mercantile interests in New York, or to banking or insurance interests in Philadelphia, or to planter elites in Virginia and South Carolina. Lawyers representing other constituencies tended to identify with them. Though its republican rhetoric asserted that the bar should have been monolithic, in practice it was not, giving rise to concerns about the profession's integrity.

Identification of lawyers with or by their clients had a ripple effect on contested views about ethical norms. If a lawyer had close social ties with his clients, zealous advocacy on their behalf could be assumed - it would seem to follow naturally from the perception that the moral universe or behavior of client and lawyer tracked each other. Hence there would be little need to question the acts of representation undertaken, thereby enhancing the lawyer's professional discretion. A lawyer who did not have the luxury of representing clients with whom he was economically or socially associated could not risk developing a reputation for less than complete devotion lest he endanger his future prospects. A lawyer who had to devote himself to a client to maintain that relationship or forge new relationships, that is, lacked discretion. Yet ultimately, whether a lawyer was comfortable representing interests he found congenial or was economically dependent on his client and therefore zealous, the organization of practice tended to inhibit the ethical standards of disinterested republicanism, or to inhibit the lawyer's appreciation of the tension in the marketplace that reduced their relevance.

During the century before the Civil War, social changes slowly occurred in the nature of practice. Partnerships emerged, though they were still the exception and not the rule, and may not have been very stable. Typically a partnership was composed of two attorneys who, because of the increased press of business, divided their responsibilities between litigation and office practices; the so-called office lawyers dealt with a growing diversification of practice, no longer just pleading, trial preparation, and jury work. Drafting instruments, planning transactions, and advising clients as to what was possible and what was not became the province of the office lawyer, who rarely entered a courtroom. Sometimes partnerships were formed between older and younger attorneys - the younger at first managing the office and preparing documents - somewhat akin to the apprenticeship relationship. The move toward partnerships tended to signal a recognition of the increased pace and complexity of practice.

Combining forces paved the way for another shift in practice, a subtle move toward specialization. There had always been pockets of specialization. The Supreme Court bar, composed of lawyers like Pinkney, Webster, and Wirt, was known for its oratorical skills in appellate advocacy. Trial 
lawyers like Rufus Choate or Lincoln were renowned for their forensic and rhetorical skills. But now specialties along the lines of specific areas of law began to emerge; they were technical, complex, and narrow. For example, bankruptcy law experts, still mostly solo, developed around the short-lived federal Bankruptcy Acts. Lawyers who might once have been generalists now devoted more of their time to one subject, where their talents and expertise could be honed more and more by repetition and familiarity. There were maritime lawyers, insurance lawyers, railroad lawyers, patent lawyers, finance lawyers, bank lawyers, factor and agent lawyers, and creditor lawyers - all primarily devoted to stoking the engine of economic development, and many focused on moving money as well as goods and services. In a number of ways, specialization fed the segmentation of the profession. As we have seen, the economic status of the client helped define the social and professional status of the attorney.

Increasingly, lawyers tended to cluster in cities. Eventually, particularly after the Civil War, the cities would become the home to larger law offices and law firms as demand for complex work across a variety of legal services exceeded the capacities of individual attorneys. Law practice was slowly forced to adapt to meet the multiple needs of clients in an interdependent world. Representing complex organizations in the various facets of their own corporate lives or in legal relationships with other complex organizations required more than one or two lawyers. The division of labor between litigation and office work was no longer sufficient: office work in particular could involve a whole new wave of planning and drafting demands, and integration with the world of commerce and enterprise.

Lawyers were skilled, if not always at shaping markets, at least in adapting to them. The organization and structure of practice moved fitfully toward life in the post-Civil War economy: more urban, less rural; more industrial, less agricultural; more expansive and interconnected, less local and isolated. Solo practitioners remained the backbone of the profession in numerous small communities, but the idea of the law firm was slowly taking shape.

\section{LAW AND LAWYERS}

On one matter, most lawyers of any intellectual stripe between the Revolution and the Civil War could agree: law either was a science or should be a science. But exactly what the meaning of science was or what consequences flowed from law being a science was deeply contested. The critical question was the relationship of law as a science to civic virtue. The republican lawyers and their ideological descendants, the Federalist-Whig elites, strove mightily to capture the high road of the rhetoric of law as a science and, therefore, to seize and define the terms of the debate. 


\section{The Science of Law and the Literature of Law}

For most republican lawyers, establishing legal science became a crucial organizing idea in the republican program, whether in legal education or political engagement. It was, they thought, the special responsibility and province of educated lawyers to ensure that private and public decisions were grounded in or sanctioned by the solid principles of law verifiable as a science. Precisely what this meant was a little unclear, but certain basic principles seemed generally accepted. First, law was a product of reason rather than passion, and therefore restrained the base or corrupt instincts of man. Second, law could be derived from principles that could be deduced in a systematic and orderly fashion from the mother lode of the common law, which was in turn derived from reported appellate cases. Third, law meant stability, order, certainty, and predictability as, over time, it developed culturally sanctioned norms or rules that tended to resist change, but were capable of slowly adapting to measured progress that would serve the greater public good. Others might have a different definition of the science of law. Jacksonians found the science of law to be a political science, grounded in positive law, the will of the people. Protestant Baconians found the science of law in natural theology filtered through the Scottish Enlightenment, preferring the methods of inductive natural science to deduction. But the republican vision of law dominated the debate, and every competing theory began by positing an alternative to it. Once generally embraced, how did the idea of legal science contribute to the formation of the literature of the law? The impact can be measured in three developments in the literature: law reports, legal treatises and commentaries, and legal periodicals.

The proliferation of American law reports was both a response to the demand from the profession for certifiably "decided" law and a result of its need for a reflective distillation of the rapidly increasing numbers of judicial decisions. The first reporters in the late eighteenth century were entrepreneurial actors meeting a perceived market; by the early nineteenth century the states and the federal government had begun to commission official law reports. Judicial reports satisfied the profession's demand for indigenous American law to reduce reliance on English precedents and to cope with the vast expansion in market activity that was a hallmark of the Early Republic.

In I 807 , at the outset of the growth of law reports, a young lawyer named Daniel Webster, reviewing a volume of reports for a literary journal, made explicit the connection between case reporting and legal science:

Adjudged cases, well reported, are so many land-marks, to guide erratick opinion. In America the popular sentiment has, at times, been hostile to the practice of deciding cases on precedent, because the people, and lawyers too, have misunderstood their 
use. Precedents are not statutes. They settle cases, which statutes do not reach. By reference to books, an inquirer collects the opinions and arguments of many great and learned men, on any particular topick. By the aid of these, he discovers principles and relations, inferences and consequences, which no man could instantaneously perceive. He has, at once, a full view of his subject, and arrives without difficulty, to the same conclusion, to which, probably, his own mind would in time have conducted him by a slow and painful process of ratiocination. ${ }^{\mathrm{I}}$

In the canon of republican legal science, the identification of precedents from which followed order and stability was necessary to forestall incursions of "popular sentiment."

The second development in the literature of law was the appearance of commentaries and treatises, some as American versions of English editions, but increasingly over time, purely American volumes on various specific legal subjects. Blackstone had provided the model for the organization of legal knowledge for Americans, and he was emulated first in St. George Tucker's version of Blackstone in 1803 , which sought to provide an American legal and political adaptation, and then by James Kent, whose four-volume Commentaries were published between I 826 and I 830 . But the general classification of principles for study and application, though invaluable, needed supplementation as law practice became more varied and, in some manner, more technical. Lawyers wrote treatises covering in depth a range of subjects: water rights, corporations, insurance, evidence, contracts, damages, and international law. Most prominent among the treatise writers was Joseph Story, who wrote on the Constitution, equity, bailments, agency, partnership, promissory notes, bills of exchange, and conflict of laws. Each work in its own way conveyed Story's view of legal science, mining the common law and wider sources - if necessary the civil law or the law of nations - to derive legal principles from the historical foundations of law. In a sense, Story preempted the field of treatise writing as well as providing an American model. And he presided over a rejuvenation of legal writing, though it might be a conceit to call it a "literature." Between 1760 and I840, almost 500 legal monographs (approximately 800 editions) were published in the United States, only about 90 of them (I 25 editions) in the period up to I790. (The figure does not include case reports, codes, statutes, digests, legal periodicals, or most miscellaneous pamphlets like bar orations or discourses.) Lawyers were reaching out for guidance, and Story entered the field to ensure that the guidance conformed to his view of legal science.

\footnotetext{
${ }^{\text {I4 }}$ Daniel Webster [Book Review of I William Johnson, New York Supreme Court Reports], The Monthly Anthology 4 (I807), 206.
} 
The third forum for writing about law was the legal periodical. Between I 790 and I830 a total of twelve legal periodicals were published. In I8IO, only one existed; in I 820 again only one; in I830, five. In other words, early in the century very few legal periodicals generated enough interest or subscribers to survive. Between 1840 and 1870 , in contrast, thirty-seven were formed, and more of them survived at least for the short term. They were an eclectic mix; most were utilitarian, printing early notices of decided cases, or book reviews of new treatises, or surveys of new statutes. But some, like American Jurist and Law Magazine, published in Boston between I829 and I843, the Monthly Law Reporter also published in Boston from I838 to I866, and the Western Law Journal published in Cincinnati from I 843 to I853, had higher aspirations, publishing essays on subjects internal to the bar and on topics of general public concern to lawyers as well. The founding editor of the Monthly Law Reporter, Peleg Chandler, divulged to Joseph Story, his mentor at Harvard Law School, his reasons for beginning the journal: "A great deal is said in particular cases, even in arguments to the court, about what the law ought to be or might well be, but precious little of what it is." What was needed, Chandler insisted, was "to hold up before the profession and the public the decisions fresh from the court - to place before them the law as it comes from the dispensers of it - from those who are too far removed from the public to be easily affected by the changing fashions of the day...." By so doing, his magazine would illustrate why "[n]oisy radicals are not men who have read intimately the reports and become acquainted with the intricate machinery, of which, if a part be disarranged, the whole may suffer...." Is Appealing directly to Story's understanding of legal science, Chandler sounded very much like Daniel Webster a generation before, applauding the arrival of law reports. He assumed that finding and stating "what it is" was a scientific undertaking.

As Chandler more than hinted, engaging in this pursuit of legal science had political consequences. Lawyers in a republic had a responsibility to be engaged in civic discourse, reasoning and arguing for the most effective legal rules in the public interest. Lawyers from the time of the Constitutional Convention in Philadelphia onward had gravitated toward the public, political arena, whether in legislatures, or state constitutional conventions, or executive offices. In Massachusetts from I 760 to i 8 Io, just over 44 percent of all lawyers were elected to some public office; from i 8 IO to I840, about a third of all Massachusetts lawyers were elected to public positions. (There is some evidence that lawyers served extensively in public positions throughout the nation.) Essays that Chandler published hence investigated the social, economic, and political implications of the scientific principles

\footnotetext{
${ }^{\text {I5 }}$ Peleg W. Chandler to Joseph Story, December I, I 838.
} 
of law they presented. To fulfill its mandate for civic virtue, a governing elite needed information and a forum to work out its arguments.

The legal science expounded in and by law reports, treatises, and periodicals also served an instrumental purpose, reinforcing the notion that only lawyers, scientifically and technically trained, could be trusted with law. Ironically, the anti-lawyer complaints that law was inaccessible and too complex might be true after all: only lawyers had sufficient command of arcane procedures and pleading, complex doctrine, and strange language. Through its literature, the bar justified its role to itself and the public by separating itself off - a special professional group, different from others in society. Law was the domain of lawyers. Their expertise, they argued, qualified them to administer the legal system and to resist the inroads of any non-scientific thought as they defined it.

\section{The Common Lawyer and Codification}

No technical issue of law reform so agitated the elite and academic lawyers in the nineteenth century as codification. At its core, the project of codification undermined the legal profession. By questioning the legitimacy of the common law and offering an alternative vision of law in a democratic society, codifiers challenged the central role lawyers played as guardians of the repository of law. As a result, there was much heated rhetoric on the subject. Whether the threat of codification was ever palpable is an interesting question, but at the very least codifying ideas was a political challenge to lawyers' control over the content of law.

The codifying impulse has a long history in America, beginning at least with the Puritans. Arguably the state and federal constitutions are examples of the art. So it is a little difficult to understand why the common lawyers were so upset at the appearance of arguments on the subject. Codification was never an organized movement. In fact, there were at least three distinct strands to the call for legal codes: a middle-class complaint about the common law, a social activist complaint, and a purely lawyerly complaint (with overtones of social activism). All criticisms focused on the perceived failings of the common law to provide responsive legal solutions to current social problems. Codifiers argued that the common law was bogged down by inaccessible technicalities derived from outdated British, not American, experiences and that lawyers manipulated the common law for their own self-interest, not the public's interest. In other words, law and lawyers were failing to deliver on promised republican virtue, and therefore, the making and administration of law should be returned to its true source in a democracy, the people, by having elected representatives in the legislature (who, ironically, might be lawyers) draft laws truly reflecting the will of the 
people. In the face of these charges, the common lawyers sought in effect to co-opt the arguments by transforming the debate into an internal legal discussion, rather than an ideological conflict.

The middle-class strand of codification drew its inspiration from prevailing anti-lawyer sentiment. The concerns expressed in the 1780 s in Benjamin Austin's pamphlet, seeking abolition of the "order" of lawyers, slowly led to reconsideration of the nature of the law being practiced. In I805, Jesse Higgins questioned the adequacy of the common law in a pamphlet entitled "Sampson against the Philistines; or, the Reformation of Lawsuits; and Justice Made Cheap, Speedy and Brought Home to Everyman's Door: Agreeably to the Principles of the Ancient Trial by Jury, before the Same Was Innovated by Judges and Lawyers." Higgins did not call for codification. Rather he thought lawyers made lawsuits expensive and time consuming and so suggested a system of arbitration to restore "cheap, speedy" justice, devoid of complexity. All that lawyers did, according to Higgins, was capitalize on people's distress and pull communities apart, rather than bind them together as republicanism required: "[T] he whole body of common law, the whole body of pleading, rules of evidence, \&c. have no legislative vote to establish or even to define them. They depend wholly and entirely for their authority on notes taken by lawyers and clerks, about this very time, and hence the judges become the legislators." In addition, "all those laws which relate to property, ... which are just and ought to be valid, are in every age and every country, the simplest rules, and fittest to the plainest capacities; ... that any and every ignorant man ... can decide any question agreeable to law, although he never heard a law read, or read one during his life." ${ }^{\prime 6}$

Higgins' middle-class lament was a central component of codification: Legislate, simplify the rules, state them clearly, make life easier, and reduce our dependence, financial and otherwise, on lawyers. Restore law to its roots in justice and reduce the power of lawyers.

The ideological origin of the common law was a distinct issue that attracted the attention of codifiers who had pursued an agenda of social activism, sometimes perceived as radical change. The social activists drew their criticisms from their causes: labor, antislavery, and religious tolerance. William Sampson, an Irish emigré attorney in New York, provides an example. His defense of New York City journeymen cordwainers in I 809 anticipated his more thorough-going call for codification in I823 in his "Anniversary Discourse... on the Nature of the Common Law." Sampson attacked the nature of the cordwainers' indictment for conspiracy at common law for seeking to exercise their power as a nascent labor union.

\footnotetext{
${ }^{16}$ [Jesse Higgins], Sampson Against the Philistines... I 6, 27 ( I 805).
} 
Sampson's criticism of the common law was organized into four separate categories. He asserted that in America, at least formally under law, all men are or should be equal: "[T] equal rights of men, and whatever is an attack upon those rights, is contrary to the constitution. Whether it is or is not an attack upon the rights of man, is, therefore, more fitting to be inquired into, than whether or not it is conformable to the usages of Picts, Romans, Britons, Danes, Jutes, Angles, Saxons, Normans, or other barbarians, who lived in the night of human intelligence." Second, in England statutes were vehicles of inequality. "[T] $[$ he English code and constitution are built upon the inequality of condition in the inhabitants... There are many laws in England which can only be executed upon those not favoured by fortune with certain privileges; some operating entirely against the poor." ${ }^{7} 7$ Third, in America, statutes created equality; the common law was the source of inequality. Indictments at common law in the United States, therefore, were suspect because they were at variance with America's enlightened constitutional tradition. Finally, Sampson suggested that statutes were to be trusted because they had involved a process of filtration through the will of the people who were ever vigilant about equality. Codification, he added in I823, would guarantee that "[o]ur jurisprudence then will be no longer intricate and thorny." 8

The attacks that defenders of the common law found most difficult to deflect came from lawyers, many of them Jacksonian Democrats, who challenged the basic underlying political legitimacy of an uncodified law in a democracy. Robert Rantoul, tied to social reform movements and risking ostracism in Brahmin Boston, threw down the gauntlet in 1836. Judgemade common law, according to Rantoul, was simply judicial legislation. Judges had arbitrary power because the common law provided no certain and predictable rules. Law should be "a positive and unbending text," not maneuvered by lawyers in front of judges. "Why," asked Rantoul, "is an expost facto law, passed by the legislature, unjust, unconstitutional, and void, while judge-made law, which, from its nature, must always be expost facto, is not only to be obeyed, but applauded? Is it because judge-made law is essentially aristocratical?" This was a charge that republican lawyers like Joseph Story strangely might have found apt or congenial. An aristocracy, Rantoul suggested, that is indebted to the feudal barbarity of the dark ages for its power is inimical to the social needs and purpose of a modern nation.

${ }^{17}$ [Argument of William Sampson], "Trial of the Journeymen Cordwainers of the City of New York."

${ }^{18}$ William Sampson, "An Anniversary Discourse, Delivered Before the Historical Society of New York, on Saturday, December 6, I 823: Showing the Origin, Progress, Antiquities, Curiosities, and the Nature of the Common Law." 
"Judge-made law is special legislation," and, according to Rantoul, "[a]1l American law must be statute law." 19

If Rantoul supplied the ideological framework, it fell to David Dudley Field to shore up the theory and carry out the project and practice of codification. And he did so with relentless zeal, though only modest success, proposing code after code for New York and elsewhere. Field sought to demonstrate that codes rather than the common law were workable, expedient, and responsive, not inflexible and inexpedient. Codes devoted to specific legal subjects like civil procedure or criminal law would be comprehensive and transparent. Everyone would know what the law was; nothing would be mysterious. The advantage would be "the whole law brought together, so that it can be seen at one view; the text spread before the eyes of all our citizens; old abuses removed, excrescences cut away, new life infused." The "CODE AMERICA," as he put it, would contain "the wisest rules of past ages, and the most matured reflections of our own, which, instinct with our free spirit of our institutions, should become the guide and example for all nations." And for lawyers, "the great task is committed of reforming and establishing the law." 20

Most of the academic lawyers who actually noticed the push against the common law were horrified and set about their own "task" of capturing the move for codification and reshaping it to their own ends. They were led by Joseph Story, Associate Justice of the U.S. Supreme Court and Dane Professor of Law at Harvard. In I836, Story chaired a commission appointed by Governor Edward Everett of Massachusetts to determine the "practicality of reducing to a written and systematic Code the common law of Massachusetts, or any part thereof." Story set out to fend off codification by in effect rehabilitating the common law. In the process, he ended up either making concessions or engaging in contradictions, depending on how one assesses his arguments. Codes, Story argued, were cumbersome and inflexible. They could not by their very nature adjust quickly enough through the legislative process to changed social circumstances. "[I]t is not possible to establish in any written Code all the positive laws and applications of laws, which are necessary and proper to regulate the concerns and business of any civilized nation, much less of a free nation, possessing an extensive commerce...." 2 I But a limited form of codification could take place, one familiar and useful to lawyers and judges, a kind of digesting system

\footnotetext{
${ }^{\text {I9 }}$ Robert Rantoul, "Oration at Scituate, Delivered on the Fourth of July, i 836."

${ }^{2 \circ}$ David Dudley Field, "Reform in the Legal Profession and the Laws, Address to the Graduating Class of the Albany Law School, March 23, I855."

2I "Report of the Commissioners appointed to consider and report upon the practicality and expediency of reducing to a written and systematic code the Common Law of Massachusetts ...," reprinted in American Jurist and Law Magazine I7 (I 837), I 7, 30, 27.
} 
consistent with Story's view of legal science, ordering categories and principles culled from cases and judicial decisions; in other words, the common law. Indeed, Story was already engaged in a version of this process through his prodigious treatise-writing efforts.

To reject codification, however, Story had to concede implicitly that Rantoul and others had a point. Once defended by him as stable, certain, predictable, universal, and the voice of experience, the common law was now described as flexible, changing, unfixed, and capable of growth. Ironically, uncertainty was now the common law's strength compared with positive law, which could not adjust as quickly to social change: "[TThe common law of Massachusetts is not capable of being reduced to a written and systematic Code; and ... any attempt at so comprehensive an enterprise would be either positively mischievous, or inefficacious, or futile...." Instead, he argued, "the common law should be left to its prospective operations in future (as it has been in the past) to be improved, and expanded, and modified, to meet the exigencies of society" by the application of its principles to new cases only rarely supplemented by legislation. ${ }^{22}$

Here then was the spectacle of common lawyers like Story defending the common law as flexible and capable of growth. Its flexibility was its strength. Once having brandished the common law as an unassailable citadel of stability and certainty, fixed in its derivation and application, the common lawyers now transformed it into a progressive science. To ward off the view that laws should exist in positive codes, Story was willing to risk admitting that judges make law. He did so because in his mind the greater danger to continuity, order, and stability was the old fear of democratic excess - the fear that the legislature, expressing the will of the people and taking the promise of equality too seriously, might readily undermine the carefully honed certainty and predictability of property rights. What Story was really afraid of was not that positive codes might fail to adjust quickly enough to changing circumstances, but that legislatures drafting codes would actually seek to change circumstances. Story was not opposed to the common law adapting to change grounded in recognized principles; he was opposed to changes in law he saw as derived from purely political motives.

The codifiers responded that if judges actually made law - if law was merely a matter of will - then let it be roped in, rendered consistent, and made by the legislature. For all of the debate among lawyers in elite circles, codification never obtained sufficient traction among lawyers who were focused on the more mundane issues of everyday practice. But the debates did reveal what the academic lawyers thought about what lawyers should be doing and the virtue of the law they were practicing. 


\section{THE REGULATION OF THE PROFESSION: ETHICAL STANDARDS, MORAL CHARACTER, CIVIC VIRTUE,}

\section{AND THE ADVERSARY SYSTEM}

In the face of widespread public criticism of the profession, lawyers faced a dilemma: how to regulate the conduct and behavior of their profession without at the same time conceding that their critics had a point. The problem was compounded by the fact that during the first half of the nineteenth century there was virtually no formal regulation of the conduct and behavior of attorneys. To the extent there was any supervision, it appeared to be self-regulation, but not self-regulation in a modern sense governed by codes of professional responsibility with rules or principles explicitly delineated. Rather regulation seemed to be left to the individual moral compass of each attorney perhaps reinforced by the norms of a professional culture. As long as the attorneys controlled the education and admission process, they could be vigilant about the moral character of aspirants to the bar, filtering by social class or critical observation the potential rogue attorney. Occasionally the handful of functioning local bar associations might enforce discipline or recommend action by a court. But courts had few guidelines as to appropriate conduct. When confronted with charges of unethical behavior, they had to rely on vague standards drawn from a lawyer's oath or duties as an officer of the court.

As the nineteenth century progressed, the ultimate question became what the social function of the profession was and what ethical guidelines would follow from it. Was it a profession whose legitimacy was grounded in its service to the public, with ethical rules to fit accordingly, or was the profession's primary responsibility to its clients, with rules adapted to the evolving practice of law in a market economy? The real task of the defenders of the role of the profession was to convince the critics, both internal and public, that law as a higher calling always had the interests of the community in mind and that the rhetorical posture of those participating in the debates over ethics was to forge standards that would foster, if not cement, the importance of providing legal services in a government of laws, and not men. The problem was that many more men were now practicing law, and it was probably going to be impossible to account for them or to testify as to their suitability. That anxiety helped feed discussion of what it meant to be an ethical lawyer.

Two figures predominate in America's antebellum discourse on the ethical conduct of lawyers, David Hoffman and George Sharswood. They embraced slightly different positions. Hoffman, a member of the elite Baltimore bar and a Federalist in the throes of anxiety for the lost republic, attempted 
to recast the profession in a fading republican vision in fifty "Resolutions in Regard to Professional Deportment," a kind of incipient code of professional responsibility appended to the second edition of his A Course of Legal Study, published in I 836. According to Hoffman, lawyers should be guided by their moral sentiments and judgments. They should exercise a critical analysis about the justness of their client's claims and refuse to participate in pursuing unfair or wrong causes, to engage in questionable tactics to vindicate the interests of clients, or to seek unfair advantage - in other words, lawyers should always behave as virtuous citizens. Hoffman stood in contrast to the notion asserted by Lord Brougham in England in the early nineteenth century that the lawyer's role was to pursue his client's interest zealously. In resolution after resolution, Hoffman meticulously laid out how lawyers confronted with difficult situations in practice should exercise their critical, moral judgment: "My client's conscience, and my own, are distinct entities: and though my vocation may sometimes justify my maintaining as facts, or principles, in doubtful cases, what may be neither one nor the other, I shall ever claim the privilege of solely judging to what extent to go." 23 As a trained elite, lawyers should reserve the right to express their independent moral judgment, not just their professional judgment derived from their special knowledge or skill. For Hoffman, professional judgment and moral judgment went hand in hand.

Hoffman's was a nostalgia for a lost age. Suspicious of open bar admission and unsupervised legal education (with law schools slow to develop), he believed that moral codes were necessary perhaps because the elites could no longer rely on lawyers to attend to the public good. By proposing ethical rules, Hoffman seemed to be conceding that private interests were now dominant and that what were really required were special standards for a world of zealous advocacy. If the bar could no longer control admission by ties of class and status, at least it could try to influence the character of those admitted by providing them with the ethical rules, guidelines, or prescriptions that formerly they might have been assumed to possess as second nature by dint of social upbringing. Lawyers now needed the rules spelled out explicitly, since the hustle and bustle of the marketplace had become the norm. Who did the lawyer owe his primary obligation to: the public or the client? Under republican theory, as one of Hoffman's allies remarked, the lawyer "feels that his first duties are to the community in which he lives" 24 and not necessarily to his client.

\footnotetext{
${ }^{23}$ David Hoffman, A Course of Legal Study (2nd ed., I836), 755.

${ }^{24}$ Simon Greenleaf, "A Discourse Pronounced at the Inauguration of the Author as Royall Professor of Law in Harvard University (I 834)."
} 
Others were becoming less sanguine and more realistic about a lawyer's obligations. One was George Sharswood, a law professor at mid-century at the University of Pennsylvania, destined toward the end of the century to be Chief Justice of the Pennsylvania Supreme Court. In I 854, Sharswood published A Compendium of Lectures on the Aims and Duties of the Profession of Law (published in later editions as An Essay on Professional Ethics). Sharswood moved beyond Hoffman's moral imperatives. Though he was troubled by the idea of abandoning reliance on moral principles, Sharswood carefully tried to construct an ethical world that reflected law practice and yet, at the same time, constrained some of the perceived excesses of zealous advocacy. Perhaps shadowing debates in the legal periodicals of the time and justifying the value of a client-centered practice, Sharswood saw the contemporary ethical universe in shades of gray. A client should expect devotion from his attorney and an attorney must do everything he can for his client, within the law. As to distinguishing morality from law, Sharswood appeared reluctant to insist on rigid, moral stances. Lawyers might on occasion, depending on the situation, reserve the right to reject a client, but once a cause was accepted, zealous representation would follow.

Sharswood and others were in some senses on the horns of a dilemma, in part precipitated by the diverging demands of the republican tradition. Lawyers could be perceived as bastions of republican virtue by remaining independent of clients' interests and above the fray, though this was increasingly difficult in an expanding and interconnected market society, or they could embrace their clients' causes as their own and assert independence from others on behalf of their clients. Therefore, a lawyer could either evaluate from the outset whether justice was attainable in his client's cause or accept his clients more or less as he found them, and pursue justice as the client saw it, without assessing the consequences for the general community. ${ }^{25}$

Lawyers at mid-century were increasingly sensitive to charges that they were simply mercenaries. Over time, in professional journals and on other occasions, they took great pains to explain why zealous advocacy served everyone's interest, including the community. They were not entirely successful in convincing a skeptical public. They had better luck convincing themselves, but in doing so they ran the risk of conceding publicly either that the bar had a public relations problem, or that some of the charges were true, or that the profession, as perceived by elites, was in a period of decline. The risk, of course, was that if the bar recognized the legitimacy of

${ }^{25}$ A version of this point is made in Norman W. Spaulding, "The Myth of Civic Republicanism: Interrogating the Ideology of Antebellum Legal Ethics," Fordham Law Review 7 I (2003), I397, I434. 
the complaints, the next logical step would be calls for regulation, because self-regulation would be interpreted as unavailing or self-serving.

The trick for lawyers who were called on to justify the evolution of the professional norm of zealous advocacy was how to fit this norm within the warm rhetorical embrace of fading republicanism. For a profession and a public accustomed to hearing (if not as often believing) lawyers' attempts to justify the bar by invoking republican ideas about virtue and the public good, defending lawyers' own private interests was no mean task. In a democratic society concerned in theory with equality, convincing the public of the legitimacy of a self-described learned and educated elite took some doing. When it came to defending the ethical standards associated with zealous advocacy, the bar had only a few intellectual choices. It could admit that zealous advocacy was for private interest or gain. Or it could try to convince the public that zealous advocacy was yet another selfless act by lawyers serving their communities; that what lawyers were doing was consistent with republican virtue because lawyers were not acting in their own behalf, but selflessly for others; that the nature of legal representation had changed as society changed; and that lawyers were still meeting the needs of a public they had always served. Much of the anti-lawyer sentiment sought to strip away the veil of the public-spirited rationale of lawyers. The bar, attuned to the critique, tried to secure its place in society by reassuring its members that it was doing society's work and carving out ethical prescriptions to meet its needs.

\section{CONCLUSION}

In 1870 , the nature and face of the profession were about to change. The end of the Civil War set in motion forces already gathering in antebellum America. The population was expanding, and the inexorable shift from rural to urban had begun. Immigrants and the children of immigrants added diversity to what once was a relatively homogeneous population. Former slaves, now free, had to cope with the ambiguous promise of freedom. Economic growth fueled by expanding railroads, developing interstate markets, and large industrial corporate organizations with proliferating labor requirements occurred in new and increasingly complex fashion.

The bar and the practice of law adjusted as well. The organization of practice slowly shifted. Though solo practitioners remained the backbone of the profession, and apprenticeship the main means of legal education, groups of lawyers with specializations began in increasing numbers, particularly in cities, to organize themselves into partnerships and then firms. As usual, the bar's elite remained concerned about who was admitted to practice. Bar associations, long dormant, were revived to maintain standards for 
entry and behavior. Lawyers also continued to participate in political life, safeguarding the Constitution and social order and never entirely losing sight of republican virtues.

The bar refocused and redoubled its efforts to cope with the demands that shifting demographics placed on admission and professional education, with alterations in forms and organization of practice, and with the reconfiguration and restatement of ethical norms. The pressure for change was in part resisted by recurring to the lessons of the past, a reliance on redesigned and redefined commitments to public citizenship as the true calling of the profession. Over the century from the Revolution to the Civil War, the profession changed subtly to avoid or rise above criticism, adopted educational practices to control access to the profession and professional knowledge, expanded the number of lawyers and variety of practices to create and serve markets for legal services, reshaped ethical and moral standards to fit the demands of modern markets, and confronted the nature of law itself to ensure that the state served society.

The bar's invocation of change, particularly its rhetoric, was not without its ironies, not the least of which was that, contrary to elite fears, the growth and expansion of the profession would lead to enhanced power and status in society. Opportunity and equality in the long run helped maintain the status of the bar as more people became lawyers, and the goals and norms associated with the hallmarks of professionalism and expertise reinforced rather than undermined social stability. When the ideas that animated professional legal identity came under pressure, lawyers sought to capture the shifting ideology, recast it in the bar's own image, and shape the ideology to serve the profession's own purposes. As a result, as America emerged from its shattering, destructive Civil War, attorneys, unlike almost any other professional group, were positioned to lead the country's reconstruction and beyond. Lawyers had survived and prospered, and they were prepared once more to direct their energy toward their understanding of what was necessary for the public good, even as what exactly the public good was would increasingly become contested.

Of the many figures born before the Civil War who sought immediately thereafter to escape the profession's earlier limitations, three in particular, in very different ways, foreshadowed the future. John Mercer Langston, one of the few practicing African American lawyers before the war, participated in Reconstruction America in the training of African American lawyers at the newly founded Howard University Law School in Washington, DC, heralding the embrace of newly found citizenship for some or, for others, the fulfillment of the meaning of citizenship. Myra Bradwell, pursuing a lifelong professional interest in law in Chicago, fought for admission to the bar, only to be rejected in her quest for formal professional identity by a 
U.S. Supreme Court that could not allow her constitutional claim to escape their narrow views of a woman's proper role. And Christopher Columbus Langdell fled a Wall Street practice, beckoned by President Eliot of Harvard to reconstitute law as a science and reframe American legal education in the shape of the modern Harvard Law School. Langdell sought to professionalize the study of law and remove it from the dead hand of law office ritual and part-time university lecturers - all to prepare lawyers to meet the challenges of a new economic order increasingly remote from its roots. The question for the profession as it embarked on its new journey was whether it would inadvertently rediscover its past, or reject its past, or simply be condemned in new forms to repeat it. 